\title{
The Effects of Lending Interest Rates on Performance of SMES in Kenya
}

\author{
Sandra Beldine Otieno ${ }^{1 *} \quad$ Beatrice Kinanu Anyuki ${ }^{2}$ Dr. Grace Akinyi Musa ${ }^{3}$ \\ 1.Economist/ Data analyst, Nairobi, Kenya \\ 2. PhD Student, Department of Accounting and Finance, University of Nairobi, Nairobi, Kenya \\ 3. Lecturer, Department of Accounting and Finance, Technical University of Kenya
}

\begin{abstract}
Small and Medium Enterprises (SMEs) play a vital role in the country's economic growth through the creation of employment. They also contribute largely to the Gross Domestic Product (GDP) since $98 \%$ of businesses in the country are SMEs. Thus, following Kenya's Vision 2030 there has been a need to protect these enterprises. However, SMEs in Kenya have been faced with numerous challenges which are not limited to affordability of financing options. These enterprises mostly rely on financial institutions for funding, which at times offer unfavorable conditions for bank loans making it hard to access the loans. These challenges hitherto, have caused the failure of these SMEs, because, without capital, operations are minimal. Empirical research has shown that interest rates attached to loans are a major factor SMEs consider when getting loans. High lending rates discourage borrowing since repayment of such loans may take up all of the business proceeds which limits the performance of these enterprises. The study sought to analyze the effect of lending interest rates on the performance of SMEs in Kenya. The study adopted a descriptive research design with a simple linear regression model. The population of the study comprised of small business owners and financial institutions managers in Nairobi Central Business District (CBD). Nairobi CBD is Kenya's epicenter for business. The study revealed a direct relationship between interest rates and the performance of SMEs. The study recommended the need to restructure bank interest rates to be more 'consumer-friendly.' This would encourage SMEs to take up loans that will enable them finance investments and thus improve their performance. Moreover, this would pave the way for job creation which would eliminate the problem of massive unemployment in the country and bring the country closer to realizing Kenya Vision 2030.
\end{abstract}

Keywords: Interest Rate, Financial Institutions, Performance, Small and Medium Enterprises, Lending Rate

DOI: $10.7176 / \mathrm{EJBM} / 13-8-15$

Publication date: April $30^{\text {th }} 2021$

\subsection{Introduction}

Interest rates play a major role in a country's economy. Interest rate has been expressed as the price one pays for using borrowed money or loans (Kimutai \& Jagongo, 2013). Those who lend money expect to be compensated for handing over their claims for the period of the loan to the borrowers. Money creates claims because it is an asset, store of value and a medium of exchange (Mnang'at, Namusonge, \& Oteki, 2016). Interest rates are important because they control the flow of money in the economy. High-interest rates curb inflation, this is because people do not take loans because it is difficult to pay them back hence low supply of money. Low-interest rates stimulate the economy; this may lead to inflation. People are free to take up any amount of loans because it is easy to pay for them.

Financial institutions through lending are the most common source of external finance for most SMEs, which heavily rely on traditional debt to fulfill their start-up, cash flow, and investment needs. Even though the SME sector has been identified as a fast-growing sector in the country, several constraints are serving as bottlenecks to SMEs in accessing finance from financial institutions (Kwaning, Nyantakyi, \& Kyereh, 2015). High-interest rates make it difficult for SMEs to access the loans, since payment of such loans may take up all their proceeds from their business yet they need to pay their employees; Financial institutions requirement of collateral in the form of land or buildings in addition to other requirements to reduce default. Thus, SMEs find it difficult to obtain external financing from banks and capital markets given their size and characteristic opaqueness. Banks' financing SMEs face difficult financial constraints due to the lack of accurate reliable information on the financial condition and performance of small firms. In particular, banks usually hesitate to finance startups and young firms, those with insufficient collateral, or firms, which demonstrate the possibilities of high returns but are at a significant risk of loss (Kravchenko, 2011).

Though SMEs are an important source of bank profitability, Hall \& Fang (2004) established that lending to SMEs is generally riskier than larger firms. Commercial banks also monitor the company receiving the credit to determine whether it is acting per the initial contract and the firm's progression to ensure the user of funds respects the interest of the provider of funds. Doing this effectively is more problematic for SMEs than for larger firms hence banks are likely to engage in credit rationing to SMEs than to larger companies. However, obstacles are constraining commercial banks further engagement with the SME segment, including SME-related factors, 
macroeconomic factors, business regulation, the legal and contractual environment, the lack of a more proactive government attitude towards the segment some areas of prudential regulation and some bank-specific factors (Calice, Chando, \& Sekioua, 2012).

The Kenyan government in its Vision 2030 plan has identified SMEs as an important priority. This is because these enterprises create employment which is among the country's big four agendas. To achieve performance, adequate sources of finance are needed for SMEs (Kira, 2013). Bank lending to small and medium-sized enterprises (SMEs) is important to allow SMEs to start up and finance investment for growth. There has been widespread comment regarding the continued difficulty SMEs perceive in obtaining bank financing since the financial crisis of 2008 (Armstrong, 2013). In Kenya, the SMEs employs about 5.1 million people representing $74 \%$ of the total national employment and also contribute about $88 \%$ of the total job creation at any one time; they also contribute in the Gross Domestic Product of the country, whereby they contribute about 24.5\% to the GDP (Maina, 2006). There is a concern that banking systems are not providing enough support to new economic initiatives and in particular to the expansion of SMEs and the agriculture sector. Faster economic growth will not be possible without the deepening of the financial system and in particular, more financial support from the banking sector to the SMEs.

\subsection{Statement of the Problem}

The major problem of the study was the financial inadequacy faced by SMEs due to the high-interest rates associated with the provision of loans by financial institutions. Worldwide, adequate funding is genuinely cited as the major hindrance to SMEs sustainability and growth. This is why most SMEs rely heavily on financial institutions. However, acquiring loans from financial institutions has not been easy. The prevailing narrative is that high-interest rates on loans are a major factor restraining the creation of start-up SMEs and the sustainability of the ongoing SMEs (Sawaya \& Bhero, 2017). High-interest rates discourage SMEs from taking up loans since repaying such loans may take up all the proceeds from the business. In such cases, it is difficult for SMEs to grow. The rate of SMEs failure is alarming 33\% to $41 \%$ of new SMEs fail within the first five years of their business operation (Thaimuta \& Moronge, 2014). Three out of five SMEs fail within their first three years of operation in Kenya (RoK, 2011). In both developed and developing economies, SMEs contribute an average of $60 \%$ of formal employment (Katua, 2014). There exists a bank lending gap in the provision of finance to SMEs since all investments need adequate capital. Argumentatively, bank lending influences the performance of SMEs (Sabana, 2014).

Though several studies have been conducted, most of them focused on how SMEs obtain their finance or the factors which undermined their financing. A study by Calice, Chando, \& Sekioua (2012) established that they are some obstacles including SME-related factors, macroeconomic factors, business regulation, the legal and contractual environment, the lack of a more proactive government attitude towards the segment, some areas of prudential regulation and some bank-specific factors. Lending to SMEs is considered riskier than any other business this is because they provide no or less collateral and banks may be more unwilling to accept credit risk. Credit risk is critical since the default of a small number of important customers can generate large losses, which can lead to insolvency, and variation in credit risk may reflect a change in the health of a banks' loan portfolio, which in turn may influence the performance of the said financial institution (Malede, 2014). Thus, credit risk worthiness of SMEs is wanting hence lending rate is charged at a higher rate to discourage them from taking up loans. However, this study sought to fill these contextual gaps created by exclusively looking at lending interest rates and how they affect the performance of SMEs.

\subsection{Objectives of the study}

The main objective of the study was to analyze the effects of lending interest rates on the performance of Small and Medium Enterprises in Kenya.

The specific objective was;

- $\quad$ To assess the influence of lending interest rates on the performance of SMEs in Kenya.

\subsection{Null Hypothesis}

The study sought to test the following null hypothesis;

$\mathbf{H}_{01}$ : There is no significant relationship between lending interest rates and the performance of SMEs.

\section{Empirical Review}

The study reviewed both theoretical and empirical literature. Theoretical literature was based on Loanable Funds Theory. Empirical literature compared the past against the current study and thereby highlighted gaps. The study used the following variables; interest rates and performance of SMEs. 


\subsection{Loanable Funds Theory of Interest Rate}

The study adopted the Loanable Funds Theory (LFT). This is a neo-classical theory developed by a Swedish economist, Knut Wicksell (1898). He argued that the interest rate is determined by the market forces of demand and supply of loanable funds. Loanable funds refer to funds available for borrowing; these may be in the form of household savings or bank loans. According to the theory, demand for loanable funds arises from dissaving, hoarding, and investment. If the interest rates are low, the demand for loanable funds increases, whereas if the interest rates are high, the demand for loanable funds decreases. Consequently, supply for loanable funds arises from savings, dishoarding, disinvestment, and bank credit. If the interest rates are high, supply for loanable funds increases whereas lower interest rates imply a decrease in the supply of loanable funds. (Nzotta, 2014) asserted that, interest rates are determined by supply and demand funds.

The theory is important to the study in that it assumes that there are two players in the loanable funds market; the lenders and borrowers. The lenders refer to financial institutions that supply bank loans to borrowers, the owners of Small and Medium Enterprises. Thus, the prevailing interest rates depend on these two players. It is important to note that the theory focuses on some factors that may cause a change in demand and supply of loanable funds; it does not equate savings to investment. Various SMEs have different reasons for obtaining loans, thus, one cannot fully state that the owners want bank loans exclusively for investment.

The theory has been critiqued by a number of researchers on the ground that the theory assumes that interest rate is determined by the demand and supply of loanable funds. These researchers counter it with Keynes liquidity preference theory. According to Keynes, interest rate is determined by demand and supply of money. People hold money for a number of motives; transactional, precautionary, and speculative motives. When these motives come into play it would not be true to say that interest rate is determined by the demand and supply of loanable funds. Several researchers agree with this view. (Ogwuma, 2008) posits that, the determination of interest rates will be found in the money market and these are basically the supply of money and the demand for money. According to (Uchendu, 2010), the functions of interest rate are as follows: it helps to guarantee that current savings will flow into an investment that will promote economic growth, it retains the available supply of credit, generally providing loanable funds to those investment projects with the highest expected returns and it brings the supply of money into balance with the polices of demand for money.

In light of this criticism, the study saw it fit to adopt the theory since it informs the study variables; interest rates and performance of SMEs. According to (Amadi \& Akani, 2005), the loanable funds theory of interest at any time represents an equilibrium price at which the demand for credit meets those who prefer to have the interest (suppliers of credit). Furthermore, (Tokunbo, 2003) posits that the demands for loanable funds are from three sources, Government, businessmen, and consumers, who used them for investment in the economy. These studies are at par with the study's view of interest rates and how they affect the performance of SMEs.

\subsection{Literature Review}

Numerous studies have been conducted across the globe regarding interest rates and performance of SMEs. Available literature has revealed that a number of factors influence lending on the supply side (financial institutions) and demand-side (SMEs). The financial institution's size, credit risk, deposit volume, and rate of interest have been found to affect the ability of banks to advance funds to SMEs.

A study by, Calice, Chando, \& Sekioua (2012) established that banks consider that the SME lending market is large, not saturated, and with a very positive outlook. A number of obstacles are, however, constraining banks' further engagement with the SME segment, including SME-related factors, macroeconomic factors, business regulation, the legal and contractual environment, the lack of a more proactive government attitude towards the segment, some areas of prudential regulation and some bank-specific factors. Nonetheless, banks have adapted to their environment and developed mechanisms to cope with it through innovation and differentiation. The study concluded that the trend should be supported and encouraged through reforms to soften the negative impact of those obstacles which are hindering the further involvement of banks with SMEs. The current study sought to evaluate how interest rates solely affect the performance of SMEs.

Lending to SMEs is considered riskier than any other business this is because they provide no or less collateral and banks may be more unwilling to accept credit risk. According to Financial Sector Deepening Kenya (2008), one major reason why lenders are reluctant to lend to SMEs is that they lack cost-effective ways to quantify credit risk. This is because they do not have organized accounting procedures and that which is available may be of unreliable quality and accuracy. Studies point out that banks charge a high-interest premium for the borrowers who have higher credit default risk to repay the loan. An Ethiopian study on determinants of Commercial bank lending by (Malede, 2014) established that credit risk is a statistically significant determinant of commercial bank lending. Credit risk is critical since the default of a small number of important customers can generate large losses, which can lead to insolvency, and variation in credit risk may reflect a change in the health of a banks' loan portfolio, which in turn may influence the performance of the said financial institution. Thus credit risk worthiness of SMEs is wanting hence lending rate is charged at a higher rate to discourage them from taking up loans. 
Moreover, (Malede, 2014) concluded that lending interest rates had a positive insignificant relationship with bank lending. However, the current study focused on how lending interest rates affected the performance of SMEs.

A Ghanaian study by Agyapong, Agyapong, \& Darfor (2011), investigated the criteria for assessing Small and Medium Enterprises' Borrowers in Ghana. The study focused on developing an insight into the decisionmaking process which lenders employ in granting loans to SME borrowers. Questionnaires were administered on selected bank branch managers of conventional banks, rural banks, and savings and loan companies. Findings from this study brought to the fore some interesting revelations. The results indicated that when loan managers are deciding on whether to accept or reject an SME loan application, the intended purpose of the loan, repayment of the previous loan, repayment schedule, type of business activity, size of the loan relative to the size of business and availability of collateral, ranked highest on their criteria list. On the contrary, CVs of clients, government guarantee of loans, charges on assets and gearing ranked lowest on the criteria list in terms of importance. The relevant factors identified in this study showed that lenders took particular interest in risk when dealing with SMEs. This is not out of place, as every business seeks to make a profit, and thus they need to be sure of recouping their monies when they lend them out to small businesses. It is thus very necessary for SME borrowers to develop an understanding of the decision criteria used by financial institutions to increase the probability of getting their loan request approved by fulfilling the required criteria adequately. The current study, however, focused on lending interest rates.

A study in Mozambique by (Sawaya \& Bhero, 2017) on the question of interest rates and growth of SMEs in the country. The paper showed that although high-interest rates make loans to SMEs more expensive, high-interest rates on their own are not the major impediment factor affecting SMEs growth. The study involved 485 sampled SMEs from a population of SMEs in Maputo city representing Mozambique as a whole. The sample was chosen using a simple random sampling strategy. Face to face interviews were conducted using structured, questionnaires to collect the primary data. The study found that most of the SMEs that benefited from financial support did not find high-interest rates as a major stumbling block; rather the insistence on collateral and the entire support structure system existing in the country was to blame for the slow development of SMEs and their sustainability. It recommended that more support from different sectors of the economy be channeled to SMEs in a well-organized and proactive manner.

Even though financial institutions have identified the SME sector as a fast-growing sector in the country, several constraints are serving as bottlenecks to SMEs in accessing finance from financial institutions (Kwaning, Nyantakyi, \& Kyereh, 2015). Their study examined difficulties SMEs face in accessing loans, difficulties financial institutions face in lending to SMEs, and the impact of loans on the profitability of SMEs. In conducting this study, questionnaires were administered to SMEs. Credit officers in the selected banks were interviewed. The following major findings came to the fore; Interest rate on loan to the SMEs is extremely high, Repayment periods on loans to SMEs are too short making it very difficult to embark on any developmental or expansion projects, most SMEs, do not understand terms and conditions, and also oblivious of the interpretation of the percentage charged on the loans. It was also found out that small business owners normally give false information when accessing loans from financial institutions. The study suggested that the government should institute some form of tax incentives to financial institutions involved in SME lending and formulate regulatory laws to help loan recovery. SME associations must be established to unite them and serve as guarantors whenever loans are accessed. Furthermore, a study by (Eze \& Okoye, 2014) established that the lending rate is one of the major determinants of lending behavior by commercial banks in Nigeria and concluded that, it was necessary to reduce the lending rate in the economy to encourage more borrowing for economic growth.

Consequently, a Kenyan study by (Shikumo \& Mwangi, 2016) on lending to SMEs by commercial banks. Small and Medium Enterprises (SMEs) access to external finance is an issue of significant research interest to academicians. Commercial banks consider many SMEs not to be creditworthy because of their inability to meet some banking requirements. A descriptive research design was employed. The study undertook a census of the 43 commercial banks in Kenya, with full data being obtained for 36 institutions. The study used secondary data from the annual published reports of commercial banks in Kenya for a period of 5 years from 2010-2014. The data collected was analyzed through a multiple linear regression model. The study established that bank size and liquidity significantly influence (positively and negatively, respectively) lending to SMEs by commercial banks in Kenya while credit risk and interest rates have no significant influence on lending to SMEs by commercial banks in Kenya. The study recommends that lending to SMEs by commercial banks in Kenya be enhanced by adopting policies that grow the commercial banks

Evidently, from the empirical studies assessed, despite the lack of adequate funds faced by most SMEs in developing economies across the world, little literature exists with regards to interest rates on the performance of SMEs. Thus, there was a need to assess the relationship between lending interest rate and performance of SMEs.

\subsection{Conceptual Framework}

The conceptual framework showed the relationship between the independent variable; Financial institutions' 
lending interest rates and dependent variable; Performance of SMEs.

\begin{tabular}{|l|l|l|}
\hline $\begin{array}{l}\text { Financial Institutions lending } \\
\text { interest rate }\end{array}$ & Performance of SMEs \\
$\bullet$ & Bnvestment \\
$\bullet$ & Lank rate & Growth/Expansion \\
& & \\
\hline
\end{tabular}

Figure 1: Conceptual Framework

Source: Authors (2021)

H01: Depicts a relationship between Financial institutions' lending interest rates and performance of SMEs.

\section{Methodology}

The study adopted a descriptive research designThis research design has been recommended over time for studies which strive to describe opinions, characteristics and perception of the issues under study. According to (Sekaran $\&$ Bougie, 2016), a descriptive study is undertaken in order to ascertain and describe the characteristics of the phenomenon in a situation. Since the study will be interested in analyzing the effect of interest rates on performance of SMEs, the design is deemed most appropriate. Further, (Orodho, 2009) observes that descriptive survey designs are used in preliminary and exploratory studies to allow researchers to gather information, summarize, present and interpret them for the purpose of clarification.

The study relied heavily on primary data since the data collection instrument used was a structured questionnaire. Simple Random Sampling (SRS) was used to identify the number of respondents as 100 .These 100 respondents included financial institutions managers and SMEs business owners within Nairobi CBD.

\section{Data Analysis}

The study had a $90 \%$ response rate since only 90 questionnaires were answered appropriately. The following was established after data collected was analyzed:

Table 1: Linear Regression model of Lending interest rates and performance of SMEs

\begin{tabular}{|c|c|c|c|c|c|}
\hline \multicolumn{6}{|c|}{ Model Summary } \\
\hline $\mathrm{R}$ & $\mathrm{R}^{2}$ & Adjusted $\mathrm{R}^{2}$ & Std. Error & F Change & Sig. \\
\hline .632 & .600 & .581 & 3.438 & 69.25 & .001 \\
\hline \multicolumn{6}{|c|}{ Regression Coefficients } \\
\hline & & Beta & Std. Error & t-statistics & Sig. \\
\hline (Con & & 3.864 & .453 & 13.501 & .000 \\
\hline Lend & erest Rates & -1.939 & .324 & -7.902 & .001 \\
\hline
\end{tabular}

Table 1 shows a strong positive relationship between Lending interest rates and performance of SMEs. This is denoted by the correlation coefficient given as $(R=0.632)$. The value 0.60 indicates that Lending interest rates only explain $60 \%$ of the total variations in performance of SMEs. Consequently, Lending interest rates explain only $58.1 \%$ of changes in performance of SMEs as represented by the adjusted $\mathrm{R}^{2}$. It can therefore be concluded that there are other factors not studied in this study that contribute $41.9 \%$ of the changes in performance of SMEs. The model is however significant since the p-value 0.001 is less than 0.05 .

From the regression coefficients, the constant regression coefficient and that of the independent variable were $3.864(S E=0.453)$ and $-1.939(S E=0.324)$ respectively. These regression coefficients were both significant at $5 \%$ level since the p-values were less than 0.05 . It should be noted that Lending interest rates have an indirect relationship with performance of SMEs. This is seen by the negative value of the independent variable's coefficient -1.939. An increase in the value of lending interest rates leads to underperformance of SMEs since they cannot borrow money hence cannot develop themselves.

As per the given coefficients, an increase in the pre-specified aspects of lending rates by one unit will lead to a decrease in the performance of SMEs by 1.939 units. Thus, based on the significance of the regression coefficient, we express the equation for the regression model as follows:

$$
Y=-1.939 X+3.864
$$

The study thus rejected the null hypothesis $\left(\mathbf{H}_{01}\right)$ at $5 \%$ level of significance about the non-significance of the effect of Lending interest rates on the performance of Small and Medium Enterprises in Kenya.

\subsection{Findings}

The specific objective of the study was to evaluate the effects of lending interest rates on the performance of SMEs in Kenya. The study used the hypothesis; there is no significant relationship between lending interest rates and performance of SMEs. The study established that there was a significant relationship between lending interest rates 
and performance of SMEs. Furthermore, there was an indirect relationship between the two variables. An increase in lending interest rates would lead to underperformance of SMEs. This is because high lending rates discourage loan taking from financial institutions since repaying such loans may take up all of the proceeds that SMEs get from their business. As such, the business is not able to grow. Thus, most SMEs fail after three years of operation. Similar sentiments were shared by a study conducted by (Kwaning, Nyantakyi, \& Kyereh, 2015).In their study they concluded that interest rates charged on loans to SMEs is extremely high and the repayment periods for such loans are too short. This makes it difficult for SMEs to embark on developmental or expansion projects. Furthermore, most SMEs do not understand terms and conditions; they are oblivious to the percentages charged on loans. Similarly, (Eze \& Okoye, 2014) established that, the lending rate is one of the major determinants of lending behavior by commercial banks in Nigeria and concluded that, it was necessary to reduce the lending rate in the economy so as to encourage more borrowing for economic growth.

\subsection{Limitations, Justifications and Suggestions for Future Researchers}

Contextual Limitation: The study concentrated on interest rates and performance of SMEs. However, this did not compromise the quality of research as the high number of failing SMEs is a worrying trend in all developing and developed economies all over the world. Future studies should consider the areas not covered by the current study. Conceptual Limitation: Thestudy concentrated on lending interest rates and performance of SMEs. Different variables could have been applied in the same study for example management ofproceeds from the SMEs. However, this did not compromise the quality of the study as the variables helped in achieving the set objectives and hypothesis developed. Future researchers should consider new variables not considered by the current study.

Theoretical Limitations: The study applied the Loanable Funds Theory (LFT). It could have applied other interest related theories for example the liquidity preference theory. However, this did not compromise quality of the research. The theory used informed the study variables accurately. Future studies should consider using other interest related theories left out by the current study.

Methodological Limitation: The study adopted descriptive research design and simple random sampling method. It concentrated on Nairobi CBD as a result of covid-19 pandemic induced lockdowns. However, this did not compromise the quality of research. Future studies should consider other methods such as ex-post facto research design once the pandemic induced lockdowns are lifted.

\section{Conclusion}

Financial institutions: Though high lending interest rate favour them in that they are able to make more profits, they should consider SMEs. Though there are conditions to be met (Calice, Chando, \& Sekioua, 2012), there is need to establish an equilibrium point for both parties so that none of them can feel exploited from the prevailing lending interest rates.

SMEs business owners: With regards to financial institutions' loan requirements, they should consider proper accountability and provide accurate information when taking up loans. Credit worthiness is an important factor that banks consider before giving loans (Agyapong, Agyapong, \& Darfor, 2011).Thus, information symmetry is needed between SMEs and financial institutions to curb financial institutions from charging very high lending rates.

Government of Kenya: SMEs are an important aspect of the economy as far as Kenya's Vision 2030 is concerned. They create employment, which is one of the big four agendas in the vision. Thus, there is need to protect these enterprises. This could be through allocating funds or through the central bank to limit the percentage of lending interest rates imposed by financial institutions. In so doing, SMEs would be encouraged to take up loans and boost their performance.

\section{References}

Agyapong, D., Agyapong, G. K., \& Darfor, K. N. (2011). Criteria for Assessing Small and Medium Enterprises' Borrowers in Ghana. International Business Research, 132-138.

Amadi, S. N., \& Akani, W. H. (2005). Interest rate and private domestic investment in Nigeria (1993-2004). Niger Delta University Press.

Calice, P., Chando, V. M., \& Sekioua, S. (2012). Bank Financing to Small and Medium Enterprises in East Africa: Findings of a Survey in Kenya, Tanzania, Uganda and Zambia. African Development Bank Group.

Eze, O. R., \& Okoye, V. (2014). Appraisal of Determinants of Lending Behaviour of Deposit Money Banks in Nigeria. International Journal of Scholarly, 142-155.

Hall, C., \& Fang, Y. (2004). Active risk management of SME lending through on-line platforms. The APEC entrepreneur consortium: Hua Hin Thailand: The Financiers Perspective .

Katua, D. N. (2014). The Role of SMEs in Employment Creation and Economic Growth in Selected Countries. International Journal of Education and Research , 461-472.

Kimutai, C. J., \& Jagongo, A. (2013). Factors Influencing Credit Rationing by Commercial Banks in Kenya. 
International Journal of Humanities and Social Science, 3(22), 244-252.

Kira, A. R. (2013). The Evaluation of the Factors Influence the Access to Debt Financing by Tanzanian SMEs. European Journal of Business and Management, 1-24.

Kravchenko, N. (2011). Determinants of Small Business Lending. Masters Thesis. Colorado State University.

Kwaning, C. O., Nyantakyi, K., \& Kyereh, B. (2015). The challenges behind SMES' access to debt financing in the Ghanaian Financial Market. European-American Journals, 16-130.

Malede, M. (2014). Determinants of Commercial Banks Lending: Evidence from Ethiopian Commercial Banks. European Journal of Business and Management, 109-117.

Mnang'at, S. A., Namusonge, P. G., \& Oteki, E. B. (2016). The Effects of Interest Rate on Financial Performance of Micro Enterprises: A Case Study of Makutano Township in West Pokot County. International Journal of Novel Research in Marketing Management and Economics, 3(3), 22-29.

Nzotta, S. (2014). Money, banking and finance: Theory and practice. (Revised Edition ed.). Owerri: Husdon-Judge Publication.

Ogwuma, P. A. (2008). The control of the monetary and banking system. The CBN Bulletin., 20(2).

Orodho, J. (2009). Elements of Education and Social Science Research. Nairobi Kanezja.

Sabana, B. (2014). Entreprenuer Financial Literacy, Financial Access, Transaction costs asnd Performance of Micro Enterprises in Nairobi City County, Kenya . PhD Thesis; University of Nairobi.

Sawaya, A., \& Bhero, S. (2017). Are Interest Rates a Deterrent to SMEs Growth in Mozambique? European Journal of Business and Management, 33-41.

Sekaran, U., \& Bougie, R. (2016). Research Methods for Business. Wiley.

Shikumo, D. H., \& Mwangi, M. (2016). Determinants of Lending to Small and Medium Enterprises by Commercial Banks in Kenya. IOSR Journal of Economics and Finance, 7(4), 57-63.

Thaimuta, J. M., \& Moronge, M. (2014). Factors affecting the performance of matatu paratransit venture in small and medium enterprises in Nairobi County. International Journal of Current Business and Social Sciences 2014, 1(2), 1-17.

Tokunbo. (2003). Liquidity management in the Nigeria economy. Suprasfied Publishers.

Uchendu, O. A. (2010). Interest Rate Policy, Savings and Investment in Nigeria. CBN Economic and Financial Review, 31(3), 34-52. 